\title{
JOURNAL.RU
}

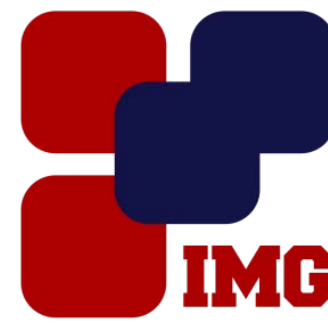

IVANov
Management
GROUP

${ }^{1}$ Атаев А.В., ${ }^{2}$ Тавасиев Г.В.

${ }^{1}$ Российский институт стратегических исследований

Москва, Россия

${ }^{2}$ Северо-Осетинский государственный университет им.К.Л.Хетагурова

Владикавказ, Россия

doi: 10.18411/lj-25-12-2016-2-05

idsp 000001:lj-25-12-2016-2-05

\section{Социально-экономические особенности Республики Северная Осетия- Алания в середине XX века}

\section{Аннотация}

В статье рассматриваются особенности социально-экономического развития Северной Осетии в середине XX века. Проводится сравнительный анализ экономического, социального и демографического развития республики с субъектами Российской Федерации.

Ключевые слова: экономическое развитие, сравнительный анализ, административно-территориальные образования, территориальная дифференциация.

Практически на протяжении всего XX в. Северный Кавказ рассматривается, прежде всего, как поставщик сельскохозяйственной продукции. Это в значительной мере повлияло на характер и темпы урбанизации, на скорость и завершенность ее процессов.

В 1926 г. в городских поселениях Северного Кавказа проживало (1,7 млн.чел. (19,1\% всех жителей региона), в сельской местности - 7,4 млн.чел. В последующем рост численности городского населения ускорился. За 1926-1938 гг. численность городского населения увеличилась на $76,8 \%$, а численность сельского - сократилась на $1,9 \%$. Удельный вес городского населения поднялся с $19,1 \%$ до $29,9 \%$ [1].

За 1939-1958 гг. численность городского населения увеличилась на 61,2\%, а численность сельского - уменьшилась на $9,2 \%$. В результате удельный вес городских жителей поднялся до 42,8\%. Однако и к 1959 г. Северный Кавказ являлся одним из слабоурбанизированных районов Российской Федерации. Только Волго-Вятский и Центрально-Черноземный районы $(27 \%)$ уступали Северо-Кавказскому по доле городских жителей. 
С 1959 г. численность городского населения Северного Кавказа стала расти быстрее, чем в целом по Российской Федерации. Повсеместный рост числа городских жителей сопровождался ростом числа городских поселений. На Северном Кавказе темпы роста числа городских поселений в 1959-1988 гг. были выше, чем в среднем по Российской Федерации. Особенно быстро росло число городов, которые возникали чаще всего путем преобразования крупных сельских поселений в городские. Иными словами, если на Северном Кавказе одним из главных источников роста численности городского населения были административные преобразования, то в целом по России рост численности городского населения происходил в основном за счет роста численности населения крупных городов. Если средняя людность городских поселений Российской Федерации росла, то на Северном Кавказе она снижалась.

За 1959-1988 гг. городское население Северо-Кавказского экономического района (СКЭР) увеличилось на 91,1\%, в то время как в целом по Российской Федерации - на 75,2\%. Особенно быстро росло городское население в 19591969 гг., когда оно выросло в Российской Федерации на 31,4\%, а на Северном Кавказе - на 43,2\%. В среднем за год городское население Российской Федерации росло на 2,85\%, а Северного Кавказа — на 3,93\%. В 1970-1978 гг. темпы прироста численности городского населения на Северном Кавказе снизились почти вдвое и стали чуть ниже, чем в целом по России. В 1979-1988 гг. темпы прироста численности городского населения стали еще более низкими. Однако северокавказские темпы прироста вновь стали несколько выше общероссийских [2].

Таким образом, Северный Кавказ выделяется на фоне средних показателей в целом по Российской Федерации низким удельным весом городского населения, при высокой средней людности городских поселений и высокой их густоте (при повышенной доле городов). Кажущаяся противоречивость объясняется весьма просто: при удельном весе территории в $2,1 \%$, Северный Кавказ концентрировал 9,1\% городского населения Российской Федерации. Относительно Северной Осетии можно отметить, что на фоне Северного Кавказа она выделяется высоким удельным весом и высокой густотой городских поселений. При удельном весе территории республики в общей площади СКЭР в 2,25\%, Северная Осетия концентрирует 4,67\% всего городского населения экономического района.

Численность сельского населения в Российской Федерации сокращалась на протяжении всего периода 1926-1988 гг. На Северном Кавказе сокращение численности сельского населения наблюдалось не всегда. Так, в 1959-1969 и 1979-1988 гг. наблюдалось увеличение численности сельского населения. Да и в другие периоды темпы сокращения были значительно ниже, чем в целом по Российской Федерации.

К 1959 г. Северный Кавказ концентрировал 11,9\% сельского населения России, а к 1989 г. - уже 18,3\%16. Таким образом, налицо все большая концентрация сельского населения России на Северном Кавказе [3]. 
Потеряв всякую надежду на государство и работу от него, население из других регионов России (Европейского Севера, Сибири и Дальнего Востока) прибывало на «теплый» и «сытый» Северный Кавказ в надежде прокормиться от земли.

\section{Литература}

1. Тавасиев В.Х., Тавасиев Г.В. Экономические и социальноэкологические проблемы городских поселений Республики Северная Осетия-Алания// Фундаментальные исследования. - 2015. - №11-7. C.1489-1492.

2. Тавасиев Г.В. Экономические и социальные проблемы в Республике Северная Осетия-Алания// Современные тенденции развития науки и технологий. - 2015. - №8-8. - С.121-124.

3. Тавасиев В.Х. Социально-демографическое развитие Северной Осетии в XX веке. - Владикавказ: Изд-во «Олимп», 2013. 